\title{
An Overview: Application of Microorganisms in Bio-Mining of Metals
}

\author{
Shazia Sana*, Deepesh Neelam, Varsha Gupta, Devki and Ravi Rahi \\ Department of Microbiology, JECRC University, Sitapura, Jaipur-303905, Rajasthan, \\ India.
}

Received: 12 Oct 2020 / Accepted: 6 Nov 2020/ Published online: 01 Jan 2021 *Corresponding Author Email: sana.sazi92@gmail.com

\begin{abstract}
Biomining of copper from ores was started during ancient era without even knowing the role of microorganisms in the process. The ever-increasing demand of metals, declination of natural resources, huge reserves of low-grade metallic ores and generation of massive amount of metallic wastes from mining and beneficiation process has led to the evolution and commercial scale adoption of biomining. The ability of microorganisms to bioamine metals depends on redox reactions, organic or inorganic acid formation and the release of complexing agents. Redox reaction is the key step of biomining process which is based either on direct or indirect bioleaching. The main difference between the two mechanisms is the direct contact between the microorganisms and the reduced minerals. Apart from the economic benefits, biomining also reduces the problem of acid mine drainage (AMD). Biomining is successfully utilized in metal recovery from low grade ores, mine tailings, mine wastes, municipal solid waste dump sites, legacy wastes, incinerator ash, E-wastes and, shales and tars etc. In this way, biomining inhibits the release of heavy metals from various types of wastes to the environment and release of toxic gases from the municipal solid waste dump sites and legacy wastes.
\end{abstract}

\section{Keywords}

Archaebacteria; bioleaching; chemolithoautotrophic bacteria $* * * * *$

\section{INTRODUCTION}

The history of mining is as ancient as the history of civilization. Many important cultural eras are identified by specific metals and its derivatives and in other words discovery of metals has shaped the evolution of civilization. 1-3. Together with agriculture, mining was the basic industry of early human civilization. Mining has a pivotal role in energy/ power industry, for infrastructure development, manufacturing industry and with fertilizer industry. Besides these benefits mining has been detrimental to environment, and human health. ${ }^{1-3}$. The environmental impacts of mining ranges from air pollution, ground water contamination, surface water pollution, siltation of water bodies and agriculture lands deforestation, loss of wildlife, land degradation to acid mine drainage etc.

Due to rapid economic and infrastructure development metallurgy industry has witnessed increased demand of metals in post industrialization era. The situation gets further complexes by decrease in grades and quality of ores over the decades. ${ }^{1-3}$. Obtaining same output from the lower grades of ores is energy-, water-, capital- and laborintensive process and simultaneously it generates larger quantity of waste ${ }^{2}$ which is economically not viable by traditional mining methods.

As accessible primary metal ores become lower grade, it is economically more viable to recycle the mine wastes. ${ }^{4}$ This also reduces the problem of AMD. ${ }^{5}$ On the other hand, potential metals present 
in low grade ores, mine waste dumps and mine tailings can be recovered using the native microorganisms by process called biomining. It is particularly useful in the large-scale application for economical metal recovery. ${ }^{6}$ Unlike the conventional mining, this is less energy intensive as well as ecofriendly approach which is devoid of discharge of any hazardous substances whether it is solid, liquid or gas into the environment. ${ }^{7}$ Biomining in a broad term is the extraction and recovery of metals from their ore and waste materials through the application of living organisms. ${ }^{8}$ It includes both bioleaching and biooxidation processes. ${ }^{9}$

In bioleaching, microorganisms convert solid metal values into their water-soluble state, whereas, in biooxidation minerals get oxidized by microbial activity while the metal values still remain in the solid phase in a more concentrated form. ${ }^{10}$ Bio-oxidation is generally used as a preconditioning process. Microbes mediated oxidation of host minerals (which comprises the metal of concern) is used for concentrating precious metals in the ore (for example gold) and other such metals existing in the ore that cannot be directly recovered easily. ${ }^{11}$ Microbial solubilization of metals involves both chemical and biological process: chemical because the metal is extracted by the action of ferric ion and/or acid, and biological because microorganisms are responsible for producing these leaching agents. ${ }^{11}$ A variety of lithotrophic and organotrophic microorganisms are known to mediate these processes. ${ }^{11}$ Microorganisms have been actively involved since the early beginning of life during both mineral formation and decomposition process in earth's crust. ${ }^{12}$ This inherent ability of mineral decomposition of microorganisms was being used in the past in leaching of copper without even knowing that this was a microorganism mediated process ${ }^{12}$ and was a pure empirical process then. ${ }^{13}$ Johnson reported that globally bio-mining accounts for production of $\sim 15 \%$ of copper and $5 \%$ of total gold production while, the contribution of other metals is even smaller. ${ }^{14}$

\section{HISTORY OF BIO-MINING}

Leaching technique of copper extraction was acknowledged by Georgius Agricola (1494-1555) a German physician and mineralogist in his work de re metallica. ${ }^{15}$ Rossi reported in his book (Biohydrometallurgy) that bioleaching of copper from ores seems to have started at least 100-200 BC in China and it was also likely to be utilized in Europe around the second century. ${ }^{16}$ Roman writer Gaius Plinius Secundus (23-79 AD) in his report described the process of copper recovery through slow passage of water through a mine in winter and subsequent evaporation of the leachate in summer. ${ }^{17}$ On commercial scale copper extraction through bioleaching was done in Rio Tinto, Spain in $1752 .{ }^{16}$ For this the heaps containing low grade copper ore were stockpiled for 1-3 years to decompose naturally and were leached by acidic ferric ion solution $\left(\mathrm{Fe}^{3+}\right)$ for copper recovery without knowing the role of bacteria in the process. The discovery of formation of acid mine drainage (AMD) by bacterial action ( $T$. ferrooxidans $)^{18}$ and the description of involvement of bacteria in copper leaching ${ }^{19}$ started a revolution in bio-mining. T. ferrooxidans was later renamed $A$. ferrooxidans. ${ }^{20}$ The chemoautotrophic acidophilic iron oxidizing bacteria was recognized to have the potential to draw the energy indirectly from the sulfide minerals and to maintain iron in an oxidizing state for the oxidation of sulfide copper ore to solubilize copper in an extreme acidic environment. ${ }^{6}$, ${ }^{14}$ The modern era of biomining started with leaching of copper run-of-mine waste rocks (Dump leaching) in USA during mid-1960s. ${ }^{14}$ In-situ bioleaching of uranium from extract residual uranium was also carried out in Canada during 1970s. ${ }^{21}$

The early commercial bioleaching applications which were limited to dump bioleaching of sub-marginal copper bearing rocks are of immense economic importance. ${ }^{6}$ The surge in biomining began in the late $20^{\text {th }}$ century after the development of modern approaches (heap leaching and tank leaching) of bioleaching/ bio-oxidation and with the application of bioleaching for other transition metals and polymetallic ores. ${ }^{14}$ Biooxidation of refractory sulfidic gold ores is another successful and extensive commercial application of biomining. ${ }^{22}$

\section{MICROBIOLOGY OF BIOMINING}

In terms of the mode of nutrition generally chemolithoautotrophic bacteria and archaea, heterotrophic bacteria and heterotrophic fungi are used for biomining process. These organisms are often referred as mesophilic because they carry out their activity at a temperature in the order of $40{ }^{\circ} \mathrm{C}$ or less.

Chemolithoautotrophs used in biomining are acidophilic microorganisms, which are having the ability to fix $\mathrm{CO}_{2}$ by oxidizing the ferrous iron or reduced sulfur and produces ferric iron or $\mathrm{H}_{2} \mathrm{SO}_{4}{ }^{12}$ Solubilization of metal sulphides by ferric iron or $\mathrm{H}_{2} \mathrm{SO}_{4}$ decreases the $\mathrm{pH}$ of surrounding and as a result further enhance the solubilization of metals, ${ }^{23}$ because low $\mathrm{pH}(1.5-3.0)$ is best for microbial leaching due to the fact that at low $\mathrm{pH}$ most of the metals stay in solution. ${ }^{24}$ Chemolithoautotrophic acidophilic Acidithiobacillus ferrooxidans, 
Leptospirillum ferrooxidans and Acidithiobacillus thiooxidans mediate in the process of bioleaching. ${ }^{25}$ Among these Acidithiobacillus ferrooxidans is the most extensively explored and commercially used bacteria for biomining. ${ }^{26}$ Acidithiobacillus thiooxidans being a facultative aerobe also thrives in anaerobic conditions by using reduced compounds of sulphur and ferric iron as an alternate acceptor of electron. ${ }^{27}$ Application of Acidithiobacillus thiooxidans and Acidithiobacillus ferrooxidans has been well established by different studies for the leaching of filter dust, ${ }^{28,29}$ filter press residues, ${ }^{28}$ sediment, ${ }^{30}$ spent catalyst, ${ }^{31,9}$ spent nickel-cadmium battery, $^{32}$ electronic scrap, ${ }^{33,}{ }^{34}$ coal fly ash, ${ }^{35}$ and municipal solid waste fly ash. ${ }^{36}$ Recovery of metals ( $\mathrm{Al}, \mathrm{Co}, \mathrm{Cu}, \mathrm{Zn}, \mathrm{Mo}, \mathrm{U}, \mathrm{V}$ ) and radionuclides from their respective ores by chemolithoautotrophs is gaining more attention. ${ }^{37-38}$ Thiobacillus and other autotrophs are also capable in bioleaching of shales, schist, and ores originating from fossil fuels. ${ }^{37,} 39$

Heterotrophic microbes thrive on organic carbon produced by autotrophs for survival and excrete organic acids as metabolites. ${ }^{12}$ These metabolites (Lactic acid, gluconic acid, citric acid and oxalic acid) make the $\mathrm{pH}$ of medium in the range of 4-6 and provide suitable medium for metal solubilization, whereas ferric iron is precipitated. ${ }^{12}$ Heterotrophs also improve the biomining ability of autotrophs by oxidizing acid soluble metal sulfide. Bioleaching of non-sulfidic rare earth elements can also be carried out by some chemoorganoheterotrophic microorganisms without maintaining low $\mathrm{pH}$ and adding sulfur and/or iron to the system. ${ }^{40}$ Heterotrophs can also consume the inhibitory substances excreted by autotrophs during oxidation and support the autotrophs by providing energy substrate which is generated during reduction of ferric iron into ferrous iron. ${ }^{41}$ The external factors such as nitrogen, sulphur, phosphorus concentration and presence of other trace elements control the growth of heterotrophic bacteria by terminating the metabolism at low concentration of nitrogen and phosphorus compounds. ${ }^{42}$

Bacillus (Bacillus licheniformis and Bacillus polymyxa) 43, 44 and Pseudomonas (Pseudomonas putida) are the most used heterotrophic bacteria for metal solubilization. ${ }^{45,25} \mathrm{AMD}$ and black shale are the prominent sources of these heterotrophic bacteria from where they have been isolated and characterized. ${ }^{46-48}$ As far as fungi is concerned, the genera Aspergillus and Penicillium are most widely used fungi in biomining. ${ }^{24}$ Aspergillus and Penicillium have been extensively used to leach and detoxify metals from silicates, ${ }^{49}$ low grade laterite ores, ${ }^{50}$ gold mine tailings, ${ }^{51}$ electro-filter dust from heavy oil combustion, ${ }^{29}$ coal fly ash. ${ }^{52}$

Role of archaebacteria of genera Sulfolobus, Acidianus, Metallosphaera, and Sulfurisphaera in bioming has also been well recognized which are extremely thermophilic sulfur and iron oxidizers. ${ }^{53,54}$ Mesophilic and acidophilic iron oxidizing archaebacteria of species Ferroplasma acidiphilum and Ferroplasma acidarmanus are also known which are capable in metal leaching. ${ }^{55}$

\section{MECHANISM AND TECHNIQUES OF BIOMINING}

The microbial (bacteria and fungi) ability of metal leaching and mobilizing from solid substances involves three principles. These are (i) redox (oxidation and reduction) reactions, (ii) acid formation (organic or inorganic acids), and (iii) the secretion of complexing agents. ${ }^{56}$

In terms of the contact between microorganisms and the minerals to be leached, the facilitation by redox reaction is based either on direct or indirect bioleaching. In direct bioleaching electrons are transferred directly from the reduced minerals (Metal sulfide) to bacterial cells. In this case close contact between bacterial cell and reduced mineral is needed. The adherence of cells to metal sulfide takes few minutes to hours ${ }^{57}$ with the help of electrochemical process. ${ }^{6}$ Microbial growth and metabolism can be negatively affected by dissolved metals, which in turns limits productivity. ${ }^{58}$ Ferric sulfate is produced by oxidation of pyrite in this mechanism. ${ }^{59}$ Non-iron metal sulfide can also be oxidized by direct bioleaching. ${ }^{60}$

The precursor of indirect leaching a lixiviant [Ferric iron $\left.\left(\mathrm{Fe}^{3+}\right)\right]$ formed by the microbes assisted oxidation of ferrous iron $\left(\mathrm{Fe}^{2+}\right)$ present in the minerals. Ferric iron being an oxidizing agent oxidizes metal sulfides and is itself reduced to ferrous iron which, in turn, get further oxidized to ferric iron by microbial activity. ${ }^{56}$ Indirect bioleaching method is most appropriate for lower sulfur and sulfide minerals as sources for $\mathrm{H}_{2} \mathrm{SO}_{4}$ production by autotrophs. ${ }^{23}$

In addition to the laboratory leaching techniques (Percolator leaching, submerged leaching and column leaching), leaching techniques used in industrial scale leaching are dump leaching, heap leaching, tank leaching and underground leaching. Brief of the industrial leaching techniques is described in Table 1. 
Table 1: Industrial scale bioleaching techniques

\begin{tabular}{|c|c|c|c|}
\hline $\begin{array}{l}\text { S. } \\
\text { No. }\end{array}$ & Technique & Features & References \\
\hline 1. & Dump leaching & $\begin{array}{l}\text { - } \quad \text { Most ancient technique. } \\
\text { - } \quad \text { eight of dumps are in the range of } 25-400 \text { meter. } \\
\text { - } \quad \text { Wump is sprinkled/ flooded from the top. } \\
\text { - Water, acidified water, or acidic ferric sulfate solution are } \\
\text { used as lixiviant. }\end{array}$ & 12 \\
\hline 2. & Heap leaching & $\begin{array}{l}\text { - The procedure of heap leaching is like that of dump } \\
\text { leaching. } \\
\text { - This technique is generally used for fine grained ores. } \\
\text { - In the heaps also there is provision of oxygen supply to } \\
\text { provide sufficient oxygen to the deeper portions. }\end{array}$ & 24 \\
\hline 3. & Tank leaching & $\begin{array}{l}\text { - This technique is expansive, but the rate of metal extraction } \\
\text { is higher. } \\
\text { - Tank leaching is established as the most effective approach } \\
\text { for bioleaching of ore concentrates and }>80 \% \text { of the total } \\
\text { zinc was leached from zinc sulfide. } \\
\text { - Tank leaching is successfully used for extraction of gold } \\
\text { from refractory gold ores. }\end{array}$ & 24 \\
\hline 4. & $\begin{array}{l}\text { Underground } \\
\text { leaching }\end{array}$ & $\begin{array}{l}\text { - This is an in-situ method of leaching. } \\
\text { - Underground leaching technique is generally done in } \\
\text { abandoned mines and in ore deposits which are too low } \\
\text { graded that cannot be extracted by conventional methods. }\end{array}$ & 24 \\
\hline
\end{tabular}

\section{APPLICATION OF BIO-MINING}

The applications of biomining as a benign and environmentally friendly technology is depicted in Table 2. Some examples of application of bio-mining/ bio-leaching technology \& its advantage over conventional pyro-metallurgical and hydrometallurgical technology is depicted in Figure 1.

Table 2: Application of microorganisms in metal recovery

\begin{tabular}{|c|c|c|c|c|}
\hline S.No & Application of bio-mining & Metals leached & Microorganisms applied & Reference \\
\hline 1. & $\begin{array}{l}\text { Low grade uranium ore } \\
\text { leaching at Uranium } \\
\text { Corporation of India } \\
\text { Limited, Jaduguda, India }\end{array}$ & $U$ & Acidithiobacillus ferrooxidans & 61 \\
\hline 2. & $\begin{array}{l}\text { Metal recovery from E- } \\
\text { waste }\end{array}$ & $\begin{array}{l}\mathrm{Al}, \mathrm{Cu}, \mathrm{Pb}, \mathrm{Ni}, \mathrm{Sn} \text {, } \\
\text { and } \mathrm{Zn}\end{array}$ & $\begin{array}{l}\text { Thiobacillus thiooxidans, } \\
\text { Thiobacillus ferrooxidans, } \\
\text { Aspergillus niger and Penicillium } \\
\text { simplicissimu }\end{array}$ & 33 \\
\hline 3. & $\begin{array}{l}\text { Metal recovery from } \\
\text { printed circuit boards (E- } \\
\text { waste) }\end{array}$ & $\mathrm{Cu}$ & $\begin{array}{l}\text { Leptospirillum } \\
\text { ferriphilum and Sulfobacillus } \\
\text { thermosulfidooxidans }\end{array}$ & 62 \\
\hline 4. & $\begin{array}{l}\text { Metal recovery from } \\
\text { printed circuit boards (E- } \\
\text { waste) }\end{array}$ & $\begin{array}{l}\mathrm{Al}, \mathrm{Ca}, \mathrm{Cu}, \mathrm{Cd}, \mathrm{Fe}, \\
\mathrm{Ni}, \mathrm{Zn}, \mathrm{Ag} \text { and } \mathrm{Pb}\end{array}$ & Streptomyces albidoflavus & 63 \\
\hline 5. & $\begin{array}{l}\text { Metal recovery from } \\
\text { cellular phone printed } \\
\text { circuit boards and } \\
\text { computer goldfinger } \\
\text { motherboards (E-waste) }\end{array}$ & $\mathrm{Au}, \mathrm{Cu}$, and $\mathrm{Ni}$ & Aspergillus niger & 64 \\
\hline
\end{tabular}


Metal recovery from

6. municipal solid waste incineration fly ash and

$\mathrm{Cu}, \mathrm{Zn}$ and $\mathrm{Pb}$ bottom ash

\section{Metal recovery from}

7. municipal solid waste incineration fly ash

8.

Metal recovery from coal fly ash

9.

Metal recovery from coal fly ash

10.

Metal recovery from spent Lithium-Ion Batteries Metal recovery from spent Lithium-Ion Batteries

$\mathrm{Al}, \mathrm{Cr}, \mathrm{Fe}, \mathrm{Ni}$
Acidothiobacillus

thiooxidans and

Acidothiobacillus ferrooxidans

$\mathrm{Cd}, \mathrm{Zn}, \mathrm{Cu}, \mathrm{Pb}, \mathrm{Mn}$,

Aspergillus niger

66

Nostoc muscorum, Anabaena variabilis, Tolypothrix tenuis and Aulosira fertilissimia

$\mathrm{Fe}, \mathrm{Al}, \mathrm{Zn}, \mathrm{V}, \mathrm{Ba}$,

Candida bombicola, $\mathrm{Mn}, \mathrm{Pb}, \mathrm{Ce}, \mathrm{Y}, \mathrm{La}$, Phanerochaete chrysosporium and Cryptococcus curvatus

Acidithiobacillus ferrooxidans and Acidithiobacillus thiooxidans

Aspergillus niger

Figure 1: Some examples of application of bio-mining/ bio-leaching technology \& its advantage over conventional pyro-metallurgical and hydro-metallurgical technology

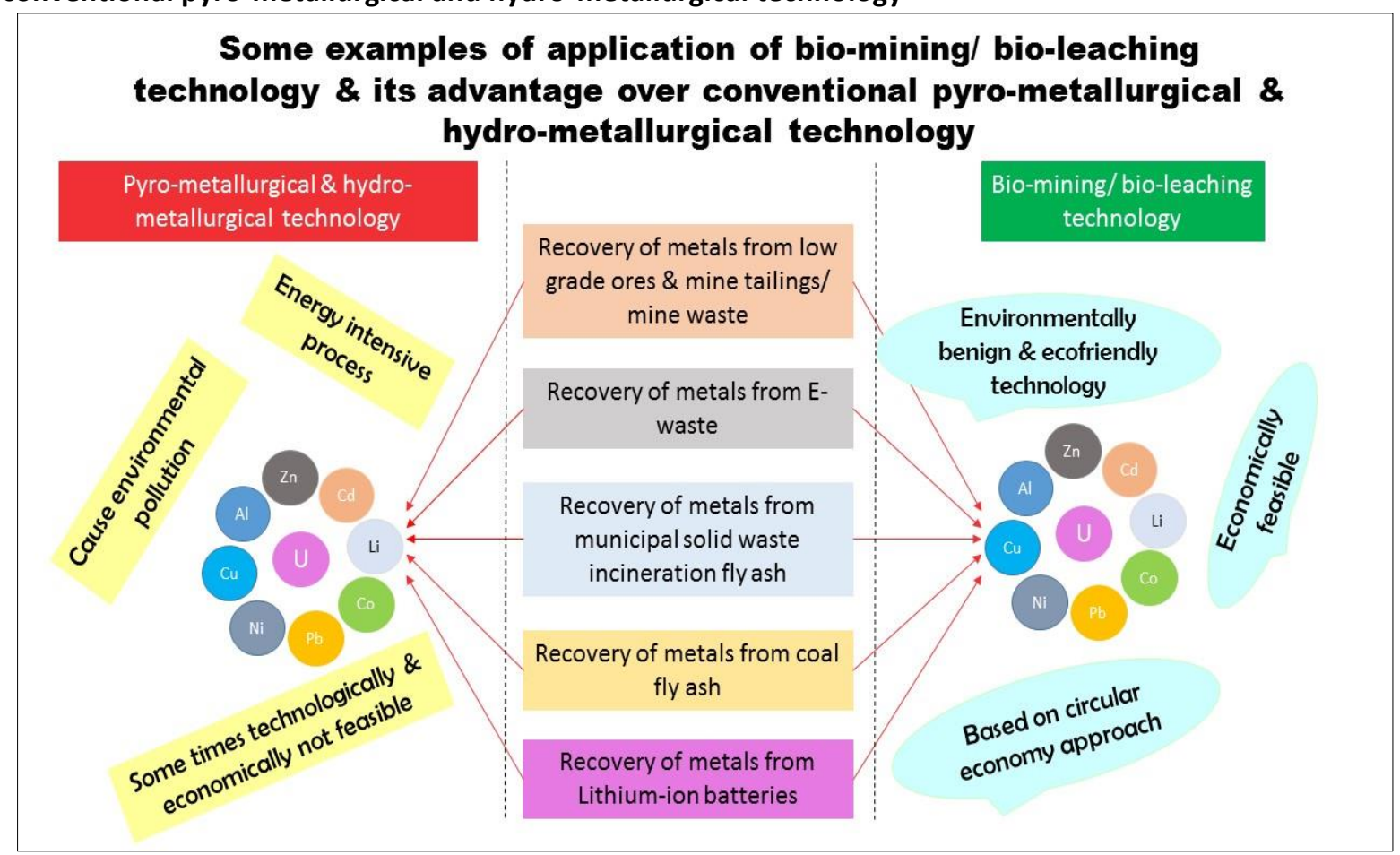

\section{CONCLUSION}

Large number of Chemolithoautotrophic bacteria, heterotrophic bacteria, heterotropic fungi and archaebacteria are known to mediate the process of biomining. Among the chemoautotrophic bacteria Acidithiobacillus ferrooxidans, Leptospirillum ferrooxidans and Acidithiobacillus thiooxidans are most exploited bacteria for biomining. Bacillus licheniformis, Bacillus polymyxa, Pseudomonas putida are the most used heterotrophic bacteria and Aspergillus niger, Penicillium simplicissimum are the most used fungi for metal solubilization. Thermophilic archaebacteria of genera Sulfolobus, Acidianus, Metallosphaera, Sulfurisphaera and 
mesophilic and acidophilic archaebacteria of genera Ferroplasma are also known to mediate metal leaching.

At present microbial mediated leaching is the best available technology to extract metals from low grade ores, mine waste and tailings, dumps of municipal solid waste and e-waste even when the metals are present in very less concentration without harming the environment and ecology. Considering the benign nature of the technology further research is still needed for extensive application of this technology for the leaching of non-sulfide ores.

\section{ACKNOWLEDGEMENTS}

All listed author(s) are thankful to JECRC University for providing the related support to compile this work.

\section{CONFLICT OF INTEREST}

Conflict of interest declared none.

\section{REFERENCES}

1. Mudd GM. The environmental sustainability of mining in Australia: key mega-trends and looming constraints. Resources Policy. 2010 Jun 1;35(2):98115.

2. Prior T, Giurco D, Mudd G, Mason L, Behrisch J. Resource depletion, peak minerals and the implications for sustainable resource management. Global environmental change. 2012 Aug 1;22(3):57787.

3. Watling HR. Review of biohydro metallurgical metals extraction from polymetallic mineral resources. Minerals. 2015 Mar;5(1):1-60.

4. Jerez CA. Biomining of metals: how to access and exploit natural resource sustainably. Microbial biotechnology. 2017 Sep;10(5):1191-3.

5. Harrison ST. Biotechnologies that utilize acidophiles. Norfolk: UK: Caister Academic Press; 2016 April 15.

6. Mishra D, Kim DJ, Ahn JG, Rhee YH. Bioleaching: a microbial process of metal recovery; a review. Metals and Materials International. 2005 Jun 1;11(3):24956.

7. Anjum F, Bhatti HN, Asgher M, Shahid M. Leaching of metal ions from black shale by organic acids produced by Aspergillus niger. Applied Clay Science. 2010 Feb 1;47(3-4):356-61.

8. JOHNSON DB. Biomining: an established and dynamic biotechnology. Microbiology Indonesia. 2012;6(4):7.

9. Bosio V, Viera M, Donati E. Integrated bacterial process for the treatment of a spent nickel catalyst. Journal of hazardous materials. 2008 Jun 15;154(13):804-10.

10. Hoque ME, Philip OJ. Biotechnological recovery of heavy metals from secondary sources-An overview. Materials Science and Engineering: C. 2011 Mar 12;31(2):57-66.
11. Bharadwaj A, Ting Y. From biomining of mineral ores to bio urban mining of industrial waste. In Environ. Technol. Manag. Conf. 4th ETMC 2011.

12. Sajjad W, Zheng G, Din G, Ma X, Rafiq M, Xu W. Metals extraction from sulfide ores with microorganisms: the bioleaching technology and recent developments. Transactions of the Indian Institute of Metals. 2019 Mar 7;72(3):559-79.

13. Ehrlich HL. Past, present, and future of biohydrometallurgy. In Process Metallurgy 1999 Jan 1 (Vol. 9, pp. 3-12). Elsevier.

14. Johnson DB. The evolution, current status, and future prospects of using biotechnologies in the mineral extraction and metal recovery sectors. Minerals. 2018 Aug;8(8):343.

15. Georg Agricola, Schiffner C. Zwölf Bücher vom Bergund Hüttenwesen: in denen d. Ämter, Instrumente, Maschinen... aufs klarste vor Augen gestellt werden. VDI-Verlag; 1977.

16. Rossi G. Biohydrometallurgy. McGraw-hill; 1990 May 1.

17. König R. C. Plinii Secundi-Naturalis Historiae. Libri XXXVII. Munich: Artemis. 1989.

18. Colmer AR, Temple KL, Hinkle ME. An iron-oxidizing bacterium from the acid drainage of some bituminous coal mines. Journal of bacteriology. 1950 Mar;59(3):317.

19. Temple KL, Colmer AR. The autotrophic oxidation of iron by a new bacterium: Thiobacillus ferrooxidans. Journal of bacteriology. 1951 Nov;62(5):605.

20. Kelly DP, Wood AP. Reclassification of some species of Thiobacillus to the newly designated genera Acidithiobacillus gen. nov., Halothiobacillus gen. nov. and Thermithiobacillus gen. nov. International journal of systematic and evolutionary microbiology. 2000 Mar 1;50(2):511-6.

21. Wadden D, Gallant A. The in-place leaching of uranium at Denison Mines. Canadian Metallurgical Quarterly. 1985 Apr 1;24(2):127-34.

22. Olson GJ, Brierley JA, Brierley CL. Bioleaching review part B. Applied microbiology and biotechnology. 2003 Dec 1;63(3):249-57.

23. Anjum $F$, Shahid M, Akcil A. Biohydrometallurgy techniques of low-grade ores: A review on black shale. Hydrometallurgy. 2012 Apr 1; 117:1-2.

24. Bosecker K. Bioleaching: metal solubilization by microorganisms. FEMS Microbiology reviews. 1997 Jul 1;20(3-4):591-604.

25. Krebs W, Brombacher C, Bosshard PP, Bachofen R, Brandl $\mathrm{H}$. Microbial recovery of metals from solids. FEMS Microbiology reviews. 1997 Jul 1;20(3-4):60517.

26. Bonnefoy V, Holmes DS. Genomic insights into microbial iron oxidation and iron uptake strategies in extremely acidic environments. Environmental Microbiology. 2012 Jul;14(7):1597-611.

27. Sugio T, Domatsu C, Munakata O, Tano T, Imai K. Role of a ferric ion-reducing system in sulfur oxidation of Thiobacillus ferrooxidans. Applied and Environmental Microbiology. 1985 Jun 1;49(6):14016. 
28. Bosecker K. Microbial recycling of mineral waste products. Acta biotechnologica. 1987;7(6):487-97.

29. Strasser $H$, Pümpel $T$, Brunner $H$, Schinner $F$. Veredelung von Quarzsand durch mikrobielle Laugung von Eisenoxid-Verunreinigungen. Arch. Lagerst. Forsch. Geol. B.-A. 1993; 16:103-7.

30. Kim SD, Bae JE, Park HS, Cha DK. Bioleaching of cadmium and nickel from synthetic sediments by Acidithiobacillus ferrooxidans. Environmental Geochemistry and Health. 2005 Sep 1;27(3):229-35.

31. Briand L, Thomas H, De la Vega Alonso A, Donati E. Vanadium recovery from solid catalysts by means of Thiobacilli action. In Process Metallurgy 1999 Jan 1 (Vol. 9, pp. 263-271). Elsevier.

32. Velgosova O, Kadukova J, Mrazikova A, Blaskova A, Petoczova M, Harvathova H, Stofko M. Influence of selected parameters on nickel bioleaching from spent $\mathrm{Ni}-\mathrm{Cd}$ batteries. Mineralia Slovaca. 2010; 42:365-8.

33. Brandl H, Bosshard R, Wegmann M. Computermunching microbes: metal leaching from electronic scrap by bacteria and fungi. InProcess Metallurgy 1999 Jan 1 (Vol. 9, pp. 569-576). Elsevier.

34. Choi MS, Cho KS, Kim DS, Kim DJ. Microbial recovery of copper from printed circuit boards of waste computer by Acidithiobacillus ferrooxidans. Journal of Environmental Science and Health, Part A. 2004 Dec 31;39(11-12):2973-82

35. Pangayao DC, Van Hullebusch ED, Gallardo SM, Bacani FT. Bioleaching of trace metals from coal ash using mixed culture of Acidithiobacillus albertensis and Acidithiobacillus thiooxidans. Journal of Engineering Science and Technology. 2014:36-45.

36. Brombacher C, Bachofen R, Brandl H. Development of a Laboratory-Scale Leaching Plant for Metal Extraction from Fly Ash by Thiobacillus Strains. Applied and Environmental Microbiology. $1998 \mathrm{Apr}$ 1;64(4):1237-41.

37. Anjum F, Bhatti HN, Ambreen A. Bioleaching of black shale by Acidithiobacillus ferrooxidans. Asian Journal of Chemistry. 2009 Aug 10;21(7):5251.

38. Panda S, Akcil A, Mishra S, Erust C. Synergistic effect of biogenic $\mathrm{Fe} 3+$ coupled to $\mathrm{S}^{\circ}$ oxidation on simultaneous bioleaching of $\mathrm{Cu}, \mathrm{Co}, \mathrm{Zn}$ and as from hazardous Pyrite Ash Waste. Journal of hazardous materials. 2017 Mar 5; 325:59-70.

39. Mishra A, Pradhan N, Kar RN, Sukla LB, Mishra BK. Microbial recovery of uranium using native fungal strains. Hydrometallurgy. 2009 Jan 1;95(1-2):175-7.

40. Rasoulnia P, Barthen R, Lakaniemi AM. A critical review of bioleaching of rare earth elements: The mechanisms and effect of process parameters. Critical Reviews in Environmental Science and Technology. 2020 Feb 25:1-50.

41. Schippers A. Microorganisms involved in bioleaching and nucleic acid-based molecular methods for their identification and quantification. In Microbial processing of metal sulfides 2007 (pp. 3-33). Springer, Dordrecht.

42. Schweisfurth R. Microbiological Fundamentals. A Working Party Report on Microbiological Degradation of Materials-and Methods of
Protection, ed by E. Heitz, AD Mercer, W. Sand and AK Tiller. 1992:4-19.

43. Grewal HS, Kalra KL. Fungal production of citric acid. Biotechnology advances. 1995 Jan 1;13(2):209-34.

44. Brombacher C, Bachofen $R$, Brandl $H$. Biohydrometallurgical processing of solids: a patent review. Applied microbiology and biotechnology. 1997 Nov 1;48(5):577-87.

45. Müller B, Burgstaller W, Strasser H, Zanella A, Schinner $F$. Leaching of zinc from an industrial filter dust with Penicillium, Pseudomonas and Corynebacterium: Citric acid is the leaching agent rather than amino acids. Journal of Industrial Microbiology. 1995 Mar 1;14(3-4):208-12.

46. Mehrotra A, Sreekrishnan TR. Heavy metal bioleaching and sludge stabilization in a single-stage reactor using indigenous acidophilic heterotrophs. Environmental technology. 2017 Nov 2;38(21):270924.

47. Sajjad W, Bhatti TM, Hasan F, Shah AA. Characterization of heterotrophic and mixotrophic acidophilic bacteria isolated from black shale and acid mine drainage, Khala Chatta, Haripur, Pakistan. Int. J. Biosci. 2015;6(8):62-70.

48. Sajjad W, Bhatti TM, Hasan F, Khan S, Badshah M, Naseem AA, Shah AA. Characterization of sulfuroxidizing bacteria isolated from acid mine drainage and black shale samples. Pak J Bot. 2016 Jun 1;48(3):1253-62.

49. Castro ID, Fietto JL, Vieira RX, Trópia MJ, Campos LM, Paniago EB, Brandão RL. Bioleaching of zinc and nickel from silicates using Aspergillus niger cultures. Hydrometallurgy. 2000 Aug 1;57(1):39-49.

50. Ghosh S, Paul AK. Bioleaching of nickel by Aspergillus humicola SKP102 isolated from Indian lateritic overburden. Journal of Sustainable Mining. 2016 Jan 1;15(3):108-14.

51. Seh-Bardan BJ, Othman R, Ab Wahid S, Husin A, Sadegh-Zadeh F. Column bioleaching of arsenic and heavy metals from gold mine tailings by Aspergillus fumigatus. CLEAN-Soil, Air, Water. 2012 Jun;40(6):607-14.

52. Torma AE, Singh AK. Acidolysis of coal fly ash by Aspergillus niger. Fuel. 1993 Dec 1;72(12):1625-30.

53. Fuchs $T$, Huber $H$, Teiner K, Burggraf $S$, Stetter KO. Metallosphaera prunae, sp. nov., a novel metalmobilizing, thermoacidophilic archaeum, isolated from a uranium mine in Germany. Systematic and Applied Microbiology. 1995 Jan 1;18(4):560-6.

54. Norris PR, Burton NP, Foulis NA. Acidophiles in bioreactor mineral processing. Extremophiles. 2000 Apr 1;4(2):71-6.

55. Edwards KJ, Bond PL, Gihring TM, Banfield JF. An archaeal iron-oxidizing extreme acidophile important in acid mine drainage. Science. 2000 Mar 10;287(5459):1796-9.

56. Brandl $H$. Microbial leaching of metals. Biotechnology. 2001 May 10; 10:191-224.

57. Ewart DK, Hughes MN. The extraction of metals from ores using bacteria. In Advances in inorganic chemistry 1991 Jan 1 (Vol. 36, pp. 103-135). Academic Press. 
58. Leahy MJ, Davidson MR, Schwarz MP. A twodimensional CFD model for heap bioleaching of chalcocite. Anziam Journal. 2004; 46:439-57.

59. Silverman MP. Mechanism of bacterial pyrite oxidation. Journal of bacteriology. 1967 Oct 1;94(4):1046-51.

60. Torma $A E$, Olsen $T M$. Kinetics of bio desulfurization of a high-sulfur coal. Applied biochemistry and biotechnology. 1988 Aug 1;18(1):341-54.

61. Mehta KD, Kumar V, Pandey BD, Tamrakar PK. Bioleaching-an alternate uranium ore processing technology for India. Energy Procedia. 2011 Jan 1; 7:158-62.

62. Wu W, Liu X, Zhang X, Zhu M, Tan W. Bioleaching of copper from waste printed circuit boards by bacteriafree cultural supernatant of iron-sulfur-oxidizing bacteria. Bioresources and Bioprocessing. 2018 Dec;5(1):10.

63. Kaliyaraj $D$, Rajendran $M$, Angamuthu $V$, Antony $A R$, Kaari M, Thangavel S, Venugopal G, Joseph J, Manikkam R. Bioleaching of heavy metals from printed circuit board (PCB) by Streptomyces albidoflavus TN10 isolated from insect nest. Bioresources and Bioprocessing. 2019 Dec 1;6(1):47.

64. Madrigal-Arias JE, Argumedo-Delira R, Alarcón A, Mendoza-López M, García-Barradas O, Cruz-Sánchez $J S$, Ferrera-Cerrato $R$, Jiménez-Fernández $M$. Bioleaching of gold, copper and nickel from waste cellular phone $\mathrm{PCBs}$ and computer goldfinger motherboards by two Aspergillus niger strains. Brazilian Journal of Microbiology. 2015 Sep;46(3):707-13.

65. Funari V, Gomes H, Cappelletti M, Dinnelli E, Fedi S, Rogerson $M$, Mayes W. Bioleaching of fly ash and bottom ash from Municipal Solid Waste Incineration for metal recovery. InProceedings of the NAXOS 2018 6th International Conference on Sustainable Solid Waste Management, Naxos Island, Greece 2018 Jun pp. 13-16.

66. Bosshard PP, Bachofen R, Brandl H. Metal leaching of fly ash from municipal waste incineration by Aspergillus niger. Environmental science \& technology. 1996 Sep 26;30(10):3066-70.

67. Kaur R, Goyal D. Heavy metal accumulation from coal fly ash by cyanobacterial biofertilizers. Particulate Science and Technology. 2018 May 19;36(4):513-6.

68. Park S, Liang Y. Bioleaching of trace elements and rare earth elements from coal fly ash. International Journal of Coal Science \& Technology. 2019 Mar 1;6(1):74-83.

69. Marcincakova R, Kadukova J, Mrazikova A, Velgosova O, Luptakova A, Ubaldini S. Metal bioleaching from spent lithium-ion batteries using acidophilic bacterial strains. Inżynieria Mineralna. 2016;17(1):117-20.

70. Horeh NB, Mousavi SM, Shojaosadati SA. Bioleaching of valuable metals from spent lithium-ion mobile phone batteries using Aspergillus niger. Journal of Power Sources. 2016 Jul 15; 320: 257-66. 